\title{
Ceramics
}

\author{
A.J. Shortland \& P. Degryse
}

Introduction

Ceramics are the most abundant surviving material on almost all Neolithic and later archaeological sites. Their abundance and ubiquity is the result of several factors. Firstly, the raw materials that are used to create most ceramics are commonly available in a wide variety of areas. Most require very little in the way of specialised processing. This means that it is generally relatively inexpensive in terms of the time and energy required to gather and process the raw materials to create ceramics. Secondly, they tend to be fragile - if dropped they are easily broken. Thirdly, the broken ceramic sherds cannot easily be reused. Unlike metals which can be sharpened or remelted, the fate of most broken ceramics is to be discarded. In contrast to the relative fragility of the complete vessel, sherds are remarkably resistant to further degradation in burial and diagenesis. This means that sherds tend to pass relatively unchanged into the hands of the archaeologist, where the reconstruction of the shape and material of the original vessel is possible. Ceramics therefore, despite their fragility, can be extremely useful, both to the societies who have employed them, usually in great abundance, and to the scientists who study them.

\section{What is a ceramic?}

The definition of a ceramic tends to vary through time and between specialisms. However, in terms of archaeology, ceramics might be defined as objects made out of clay that has in some way been processed. Clay is a naturally occurring geological deposit usually formed from the weathering of rocks. It is made up of clay minerals with a greater or lesser amount of other minerals entrained within it. Clay minerals are hydrous aluminium phyllosilicates of various compositions and structures (e.g. Klein and Hurlbut, 1998). Common clay minerals encountered in the clays used for archaeological ceramics include kaolinites, smectites, chlorities and illites. Naturally occurring clay bodies often combine a wide range of different clays within these groups. The different clay types infer slightly different properties on the ceramics which are made from them

The simplest type of ceramic would be clay that has been shaped and dried, perhaps in the sun, or near a fire. This is sometimes termed "baked clay", and makes up some of the earliest use of clay that survives in the archaeological record. One of the most important uses of this early baked clay is the manufacture of figurines, e.g. the Palaeolithic Venus figurines of Dolní Věstonice (Vandiver et al. 1989). Somewhat later baked clay goes on to form a very important source of building material in many areas of the world. In arid climates baked clay bricks are still the mainstay of architecture as they have been for many thousands of years. However, baked clay is vulnerable to damp, and rapidly turns back to clay when subjected to contact with water for any length of time. It was determined in the Neolithic material that not just baking, but firing clay was the best way for it to keep its shape (e.g. Amiran 1970). Fired 
clay can be used in cooking and storage vessels and is relatively unaffected by exposure to moisture and heat. The invention of firing allows ceramic to fulfil its full potential and is what leads to its widespread use. The most commonly found ceramic is therefore fired clay (or 'earthenware'), combined with greater or lesser additions of other materials as discussed below.

\section{What questions are asked?}

Due to the fact that ceramics are so widespread and common on archaeological sites they have been used to answer a range of different questions of interest to the archaeologist and historian. These can be divided into perhaps three different groups. The first question concerns how the ceramic was made. The technology of producing ceramics, while in essence rather simple, in practise is extensively modified and refined by different societies. A complex chaîne opératoire (Bar-Yosef et al. 1992) of different technological methods and choices can often be defined. This can reveal important information about how ceramic production is carried out - the selection, sorting, refining and mixing of raw materials, the methods of shaping and moulding and the control of temperature and oxidation state of kilns. In more recent studies this often lead on to the discussion of the place of the production process and its workers within the society as a whole and how the decisions they are making both shapes and is shaped by the culture in which they are operating (Orton et al. 1993, Rye 1981, Arnold 2008).

The second major group of questions asked of ceramics is determining what they might have been used for. This can be attempted firstly by an examination of the ceramic itself. Traditionally, archaeological science has concentrated on a technical study of ceramics - how "fit for purpose" are they?

This has involved attempting to define failure points of vessels, especially those involved in specialist operations such as metallurgical crucibles, but also cooking vessels for example. The relationship between the presence of minerals, their amounts, sizes and the performance characteristics of ceramics (e.g. thermal shock resistance, impact resistance and strength) may directly be linked with technological choices made by the potter. The magnitude of these stresses is affected by the thermal conductivity of the vessel body, bulk thermal expansion coefficient, thickness of the wall and shape of the vessel (Tite and Kilikoglou 2002). Beyond this level, the identification and classification of decoration of various types and the complexity of the production process can help to define "prestige wares" over utilitarian, and define broad groups of storage, cooking, serving, display and funerary wares amongst others. Recent work has shown that the idea of a single designed use of a ceramic is too simplistic. I. Hodder already referred to the artefacts as part of a 'material culture language', a means of communicating information between individuals and groups (Hodder 1986). As such, ceramics may serve as transmitters of information about their producer, owner or user. Ceramics have a complex life history or 'biography' which can involve several periods of different uses and re-uses more-or-less related to the purpose in the mind of the original manufacturer. Thus the evidence of several periods of use might be superimposed on each other in the ceramic. In addition to the study of the ceramic itself to determine use, there is also the possibility of 
looking at residues within the ceramic which might reflect what is held and how it was used (see Chapter 5)

The third major group of questions relate to both of the above, but go one stage beyond. This is the attempt to determine where a vessel might have been made by looking at its raw material components. Ethnographic studies of potters have shown that the raw materials of ceramic production tend to be gathered very close to the kiln site, usually within a day's journey there and back (Arnold 1985). This means that the raw materials of local ceramics are derived very locally to the production site. Considering provenance, the use of misfired sherds is highly desirable, as these are often thrown away in situ, or in close proximity to the production site, after a failed firing process (Mommsen et al. 1988).

The identification and description of a rare imported, foreign vessel or sherd in a mass of locally produced wares is perhaps the most important and certainly the most frequently asked question of the scientific study of ceramics. Non-local ceramics, because of the opportunity they give for the plotting of ancient trade and exchange networks as well as the possibility of identifying high status individuals or sites, are perhaps the most challenging and interesting parts of the analysis of this material.

\section{Analysing ceramics}

As with the study of many material types, ceramics can be studied using a range of different equipment ranging from a hand lens costing only a few pounds to analytical equipment costing millions. The huge numbers of ceramics on many sites also in itself presents challenges that are not common in other, rarer, material. There tends therefore to be a hierarchy of techniques used in the analysis of ceramics starting simply, cheaply and quickly with the bulk of the samples and selecting smaller numbers at each stage to be subjected to analysis by more lengthy and expensive techniques.

\section{Hand lens to binocular microscope}

Most initial ceramic sorting is done by eye, assisted by low power hand lens or binocular microscope. This sorting attempts to characterise the ceramic saying something of its internal composition, external make-up and shape. This is often done quite fast in order to organise sherds into groups. A key concept here that will be continued below is that of fabric (Peacock 1970,1977). The fabric analysis of a ceramic is the study and classification of ceramics based on the characteristics of the clay paste and their inclusions. This includes the colour of the matrix, hardness, feel, nature of the fracture, firing process, production process, nature of the inclusions, size of the inclusions, amount of the inclusions, and sorting of these inclusions. Fabrics are made up of the clay itself plus any other additions that have been deliberately, or accidentally, added to the clay. The most common deliberate addition to the clay is temper, a material added that changes the properties of the clay especially during firing, but also during use. Temper can include sand, straw, rock fragments, ground up broken ceramics (known as grog) and others. The reason for the selection of a particular temper 
can be technological, for example it improves the survivability of the ceramic when it is fired, but it can also be ritual, connected with tradition or religion. The appearance of the clay and temper can be moderated by the way the ceramic has been shaped. Ceramics vessels can be hand-modelled, coiled, slabbed, moulded, and thrown on various sorts of wheels (Rye 1981, Edwards and Jacobs 1986, Rice 1987, Orton et al. 1993,). Each of these has the potential of manifesting itself on the fabric, perhaps by the preferential orientation or non-homogeneous distribution of temper. These will be changed once again by the firing process, which can change the colour of the clay and develop glassy patchy or matrices if very high fired.

The surface of the ceramics can be treated with different techniques to alter the material properties of the ceramic (Orton et al. 1993). Commonly seen are relief, slips and glazes. It is very common for the surface of vessels to be decorated with incised patterns. These might be scored into the ceramic as it is drying after forming with a knife of stick, or other shapes or materials might be pressed into the surface, for example twine, to create a pattern. Another possibility is to wait until the ceramic is fully dry, but before it is fired to polish its surface, perhaps with a smooth pebble. This is known as burnishing and results in the smoother surface characteristic of this technique. This sort of decoration does not usually change the physical characteristics of the vessel very much, but does presumably make the vessel more pleasing to the eye of the manufacturer. Another possible surface technique is the application of a slip. A slip is a fine-grained clay, sometimes a finer version of the body clay and sometimes a different clay. This is either painted onto the surface or the ceramic is dipped into it. It creates a thin layer on the surface of the ceramic, which can look smoother than the main bulk of the body (Velde and Druc 1999). A 'wash' is in fact a very thin slip layer that has been applied on the pottery, and is not necessarily homogenously applied. Therefore, in contradiction to a slip layer, a wash is not entirely coated. Slips can be contrasting colours and can also be painted with pigments to create polychrome vessels. The surface(s) of the ceramic type can also be smoothed out to obtain an even surface without any pores or mineral inclusions visible. The final possibility is the glaze, which is applied to the ceramic as a slurry and then fired to create a glassy surface layer. Glazes can be many colours, can be multilayered and can themselves be painted or enamelled. They are essentially a glass adhering to the surface of the ceramic and are discussed in more detail in the chapter dealing with glasses rather than here.

The resulting macroscopic groups are often referred to as 'wares'. This term is used as "a recurring combination of distinctive attributes including colour, temper, forming and finishing techniques, characteristic vessel forms and types of decoration" (Henrickson 1994: 115). After ceramics are sorted into groups by these relatively simple techniques, then the next stage is to try to characterise the groups. There are two different ways of doing this: mineralogical and chemical. 


\section{Mineralogical approaches}

Perhaps the traditional way of characterising a group of ceramics is to examine its mineralogy. This is a technique derived from the study and description of rocks or petrography, hence the term ceramic petrography is often used. The primary tool of the ceramic petrographer is the polarising light microscope (PLM). Fragments of sherds representing the different groups of ceramic on a site are glued to a microscope slide and polished down until they are only $0.03 \mathrm{~mm}$ thick to create a thin section. At this thickness, most minerals in ceramics are translucent. The section is placed on the PLM, where it sits between two polarisers arranged at ninety degrees to each other. The minerals of the sample interact with the light, generating colours and other properties characteristic of the mineral involved. Prior to the thin section preparation, samples are often impregnated with an ultra-low viscosity resin. The resin especially fixates inclusions pores within the clay body and improve the determination of the actual porosity (Oliveira et al. 1983).

As long as the ceramic is course grained enough for the minerals to be visible, this is a very good and very well established method for identifying minerals in the raw material mixture used, the clay as well as the temper. It can also give indications of firing temperature and oxidation states. Moreover, thin section petrography may add indications for studying the formation processes of the vessels, not visible by surface examination. The orientation/alignment of mineral inclusions (e.g. micas) and voids are frequently used to identify formation processes in thin section (Vaughan 1995, Gibson and Woods 1997). Many textbooks exist on the basics of thin section petrography (e.g. MacKenzie and Adams 1994); Reedy (2008) describes ceramics specifically. The description of thin sections of ceramic material is often based on a system provided by Whitbread (1995) on Greek transport amphora, later discussed by Josephs, derived from soil micromorphology (Josephs 2005).

Thin section work by PLM is the main technique for the study of ceramics. It requires a sample large enough to be representative of the ceramic fabric as a whole, but the cost of the equipment needed is relatively low. What it does require is a good level of expertise and experience at looking at ceramic sections, which even to those geologically trained, can be difficult. To balance that, the number of minerals commonly found in ceramic sections is relatively low, certainly less than fifty, which makes their routine identification easier. Producing a qualitative estimate of the type and abundance of minerals can therefore be carried out in this way and this is often enough to distinguish different clay sources. However, applying a more quantitative approach, that is to say applying percentage values to the proportion of these different minerals is rather more difficult. The first reason for this is a fundamental one as regards thin section work - how representative of the ceramic as a whole or the clay/temper source are the relatively few instances of these in the thin sections taken? The larger and more numerous the thin sections, the more likely they are to be representative, but the larger the sample taken has to be. Secondly, there is the problem of how to count the minerals in the sections. This is normally done by point counting, that is to say setting a grid across the thin section and 
assessing which mineral is present at each grid point. However, this once more means reducing the sample size - the entire section is not counted.

The second possibility for the assessing of the mineralogy of the sample is to use a polished section and a Scanning Electron Microscope (SEM). The section is place in the SEM and the minerals identified by a combination of morphology, contrast (the brighter the mineral the higher the average atomic number of the elements it contains) and using an attached Energy Dispersive Spectrometer to compositionally analyse individual phases. This has the disadvantages of generally being slower than the thin section approach, and also it is more difficult to classify individual mineral grains using SEM that PLM. However, it is an approach which seems to be increasingly used (e.g. Tite et al. 2001). It is possible to automate the identification of grains on the SEM, so that the whole section is mapped for different elements and then grains that are the same grouped together and counted. This can give good quantitative results for the mineral analysis of the ceramic or clay.

Neither of the mineralogical techniques is suitable when the ceramic becomes too fine, or too high fired, to have a recognisable mineralogy. In these cases at least, chemical approaches have to be resorted to

\section{Chemical approaches}

The second approach to the analysis of ceramics is to go from the optical, hand specimen grouping to a bulk chemical analysis. There are several ways of doing this and as techniques have been invented and refined this has changed through time (e.g. Rice 1987, Mommsen 2001). The early approaches were to use wet chemical analysis, but this has now been completely superseded by other techniques, especially Neutron Activation Analysis (NAA), X-Ray Fluorescence (XRF), Atomic Absorption Spectroscopy (AAS), Optical Emission Spectroscopy (OES) and Inductively Coupled Plasma (ICP) techniques (e.g. Pollard and Heron, 2008). It is likely that, with the price of equipment going down and their sensitivity going up that various types of ICP will be the future of the chemical analysis of ceramics. In most of the modern chemical techniques, the sample is ground up and dissolved in acid. In terms of ICPMS, the solution is then injected into the plasma chamber of the machine, ionised and the elemental composition determined by a sensitive mass spectrometer. ICPMS, in addition to giving bulk chemical analysis for almost all elements required, has detection limits for most elements down to parts per billion (ppb) or even parts per trillion (ppt) allowing analysis of Rare Earth Elements, for example, which can give a very good signature of the clay source. The technique is therefore highly discriminatory, and combined with statistical approaches can be very good at grouping ceramics and determining outliers and imported wares. However, it does tend to hide the detail in a way that mineralogical approaches do not. Whilst it is easy to say that one group of ceramics is compositionally different to another in terms of certain elements, it can be difficult to say why that might be so. Could it be connected with different clays, different temper or amount of temper, clay processing, postdepositional environment and alteration of mineral grains, or firing? The difficulty of chemical analysis is also directly related to the sedimentary 
processes at hand, which can result in an (un)even mix of all rocks found in the environment of the basin and thus may counteract chemical differentiation (Mason and Moore 1982). With a thin section this could be investigated relatively easily, with a chemical composition this can be much more difficult. However, in pottery studies it is believed that the chemistry of sediments (and ceramics) approximately reflects the main characteristics and the chemical properties of the rocks from which they were derived in the catchment area or river system which provided them.

\section{Isotopic approaches}

Recent developments also applied radiogenic isotope ratios to the analysis of pottery $\left({ }^{87} \mathrm{Sr} /{ }^{86} \mathrm{Sr},{ }^{143} \mathrm{Nd} /{ }^{144} \mathrm{Nd},{ }^{207} \mathrm{~Pb} /{ }^{206} \mathrm{~Pb}\right.$ etc.) (Guzowska et al. 2003 , Li et al. 2006). So far, lead isotopes have hardly ever been applied to characterize the source materials of ceramics (Knacke-Loy et al. 1995; Renson et al. 2010, in press). It needs to be stated, however, that these studies are best carried out only when no other technique provides sufficient data for answering research questions. Although providing a substantial amount of information on their own, the simultaneous use of all these methods provides a more robust framework for interpreting ancient potteries.

\section{Unusual ceramics}

Whilst the vast majority of ceramics have a chemical composition that falls within a more or less continuous spectrum, there are other, specialised ceramics that have very unusual compositions. These are usually ceramics that have been developed to cope with particularly unusual conditions or requirements. Two different types are worth briefly noting here. The first are those developed for high temperature processes for example metalworking and refining. Crucible technology had to be developed in response to the desire to achieve and maintain higher and higher temperatures in the pursuit of particular alloys, perhaps especially in alchemical investigations. Clays were specially selected for their refractory characteristics and high temperature, mullite crucibles developed (e.g. Rehren 2003). The second, much larger, but related group, are the porcelains. These are pure kaolinitic clays that where high fired to produce a glazed ceramic that could have a brilliant white colour and very thin walls. These decorative vessels produced were extremely valuable and their study by SEM and ICPMS is ongoing.

When time and money permits, a combination of mineralogical and chemical approaches gives the best combination of information and is most likely to answer the archaeological questions posed (Degryse and Braekmans, 2014). The very ubiquity of ceramic finds on the majority of archaeological sites really requires this investment in their careful study. They can reveal a wealth of information impacting on a whole range of archaeological and historical questions. A carefully constructed sampling strategy informed by clear questions and combined analytical techniques still has the potential to say as much about our past as any archaeological science technique. 
References

Amiran, R. (1970). Ancient Pottery of the Holy Land: From Its Beginnings in the Neolithic Period to the End of the Iron Age. Rutgers University Press

Arnold D.E. (1985). Ceramic theory and cultural process, Cambridge.

Arnold D.E. (2008). Social change and the evolution of ceramic production and distribution in a Maya community, Boulder. University Press of Colorado.

Bar-Yosef, O., Vandermeersch, B., Arensburg, B., Belfer-Cohen, A., Goldberg, P., Laville, H., Meignen, L., Rak, Y., Speth, J. D., Tchernov, E., Tillier, A-M., and Weiner, S. 1992. The Excavations in Kebara Cave, Mt. Carmel. Current Anthropology, vol. 33 , no. 5, 497-550.

Degryse, P. and Braekmans, D. (2014). Elemental and isotopic analysis of ancient ceramics and glass. In Cerling, Th. (ed.) Treatise of Geochemistry. Volume 14: Treatise on Geochemistry in Archaeology and Anthropology. Elsevier, 191-207.

Edwards, I. and Jacobs, L. (1986) Experiments woth stone pottery wheel bearings - notes on the use of rotation in the production of ancient pottery, Newsletter. Department of Pottery Technology (University of Leiden), 4, 49-55.

Gibson A. \& Woods A. (1997), Prehistoric pottery for the archaeologist, London. Leicester University Press.

Guzowska M., Kuleff I., Pernicka E. and Satır M. (2003). On the origin of Coarse Wares of Troia VII. In Wagner G.A., Pernicka E. and Uerpmann H.P. (ed.) Troia and the Troad, Scientific Approaches, 233-249. Berlin-New York: Springer.

Henrickson R.C. 1994: Continuity and discontinuity in the ceramic tradition of Gordion during the Iron Age. In: Çilingiroğlu A. \& French D.H. (ed.) Anatolian Iron Ages 3, British Institute of Archaeology at Ankara Monograph 16, London, 95129.

Hodder (1986) Reading the Past: current approaches to interpretation in archaeology. Cambridge: Cambridge University Press.

Klein, C. and Hurlbut, C.S. (1998) Manual of Mineralogy. John Wiley \& Sons.

Knacke-Loy O., Satır M. and Pernicka E. (1995). Zur Herkunftsbestimmung der bronzezeitlichen Keramik von Troia: Chemische und isotopengeochemische (Nd, $\mathrm{Sr}, \mathrm{Pb}$ ) Unterschungen, Studia Troica 5, 145-175.

Li, B.P., Zhao, J.X., Greig, A., Collerson, K.D., Feng, Y.X., Sun, X.M., Guo, M.S. and Zhuo, Z.X. (2006). Characterisation of Chinese Tang sancai from Gongxian and Yaozhou kilns using ICP-MS trace element and TIMS Sr-Nd isotopic analysis. 
Journal of Archaeological Science 33, 56-62.

Josephs R.L. (2005) Applying micromorphological terminology to ceramic petrology, Geoarchaeology 20(8), 861-865.

MacKenzie W.S. and Adams A.E. (1994). A colour atlas of rocks and minerals in thin section, London :Manson Publishing.

Mason B. and Moore C.B. (1982) Principles of geochemistry, New York. John Wiley \& Sons.

Mommsen H., Kreuser A. \& Weber J. (1988) A method for grouping pottery by chemical composition, Archaeometry 30, 47-57.

Mommsen, H. (2001). Provenance determination of pottery by trace element analysis: Problems, solutions and applications, Journal of Radioanalytical and Nuclear Chemistry 247, 657-662.

Oliveira L., Burns A., Bissalputra T. \& Yang K.C. (1983). The use of an ultra-low viscosity medium (VCD/HXSA) in the rapid embedding of plant cells for electron microscopy, Journal of Microscopy 132, 195-202.

Orton C., Tyers P. and Vince A. (1993). Pottery in archaeology, Cambridge Manuals in Archaeology, Cambridge : Cambridge University Press.

Peacock, D.P.S. (1970). The scientific analysis of ancient ceramics: A review. World Archaeology 1, 375-89.

Peacock D.P.S. (1977). Pottery and Early Commerce. Characterization and trade in Roman and Later ceramics, London: Academic Press.

Pollard, A.M. and Heron, C. (2008). Archaeological Chemistry. Cambridge: The Royal Society of Chemistry.

Reedy C.L. (2008). Thin-section petrography of stone and ceramic cultural material, London: Archetype Publications Ltd.

Rehren, Th. (2003). Crucibles as Reaction Vessels in Ancient Metallurgy In Craddock, P. and Lang, J. (Ed.) Mining and Metal Production Through the Ages. London: British Museum Press, pp. 207-215.

Renson, V., Coenaerts, J., Nys, K., Mattielli, N., Vanhaecke, F., Fagels, N., and Claeys, Ph. (2011). Lead Isotopic Analysis for the identification of Late Bronze Age Pottery from Hala Sultan Tekke (Cyprus), Archaeometry 53, 37-57.

Renson, V., Coenaerts, J., Nys, K., Mattielli, N., Åström, P., and Claeys, P. (2007). Provenance determination of pottery from Hala Sultan Tekke using lead isotopic analysis: Preliminary results. In Åström, P. \& Nys, K. (eds.) Hala Sultan Tekke 12. 
Tomb 24, Stone anchors, faunal remains and pottery provenance, Studies in Mediterranean Archaeology, 45(12), pp. 53-60. Sävedalen: Paul Åströms förlag.

Rice P. (1987). Pottery analysis. A sourcebook, Chicago: Univ. of Chicago Press.

Rye O.S. (1981) Pottery Technology. Principles and reconstruction, Washington: Taraxacum.

Tite M., Kilikoglou V. \& Vekinis G. (2001) Strength, toughnes and thermal shock resistance of ancient ceramics, and their influence on technological choice, Archaeometry 43, 301-324.

Tite M. \& Kilikoglou V. (2002) Do we understand cooking pots and is there an ideal cooking pot? In: Kilikoglou V., Hein A. \& Maniatis Y. (ed.) Modern trends in scientific studies on ancient ceramics, British Archaeological Report International Series 1011, Oxford.

Vaughan S.J. (1995) Ceramic petrology and petrography in the Aegean? American Journal of Archaeology 99 (1), 115-117.

Vandiver, P.B., Soffer, O., Klima, B. and Svoboda, J. (1989) The Origins of Ceramic Technology at Dolni Věstonice, Czechoslovakia", Science 246, 1002-1008.

Velde B. \& Druc I.C. (1999) Archaeological ceramic materials, Berlin: SpringerVerlag.

Whitbread I.K. (1995) Greek transport amphorae: $A$ petrological and archaeological study, Fitch Laboratory Occasional Paper 4, Athens: British School at Athens. 